\title{
In Silico Study of The Component of Eleutherine americana MERR. on Human Estrogen Reseptor Alpha as Potential Anti-Breast Cancer
}

\author{
Tasia Amelia*, Dina Pratiwi, Romsiah, Daryono H. Tjahjono \\ School of Pharmacy, Bandung Institute of Technology, Jalan Ganesha 10, Bandung 40132, Indonesia.
}

Received: 16 October 2014 / Accepted: 30 November 2014

\begin{abstract}
:
Eleutherine americana (Indonesian: "bawang dayak") has been used traditionally to treat breast cancer by Borneo people. Its compounds contains eleutherine, eleutherinone, eleutherol, isoeleutherine, eleutherinol, dihydroeleutherinol, hongconin, and 6,8-dihydroxy-3,4dimethoxy-1-methyl-anthraquinone-2-carboxylic acid methyl ester. Those compounds showed inhibitory activity against HeLa cell line and 7,12-dimethylbenz(a) anthracene (DMBA) induced mice at concentration of $100 \mathrm{mg} / \mathrm{mL}$. The present study was aimed to investigate the potential compounds of Eleutherine americana as anti-breast cancer by docking method. The compounds of Eleutherine americana were docked into estrogen receptor alpha (3ERT) by using AutoDock v4.2, and the binding affinity was compared to the natural ligand (4hydroxytamoxifen). The results showed that the natural ligand has binding free energy of $-8.7 \mathrm{kcal} / \mathrm{mol}$, and eleutherinol has the highest affinity with binding free energy of $-6.43 \mathrm{kcal} / \mathrm{mol}$ compared with the other compounds.
\end{abstract}

Key words: $3 E R T$, breast cancer, docking, E. americana, Iridaceae, OHT, naphtaquinone

\section{Introduction}

Eleutherine Americana Merr. (Indonesian: "bawang dayak") is a plant with red bulbs. This plant has been used extensively by the local people of Borneo in the traditional treatment of heart diseases, inflammation, bleeding, and tumor, especially in the treatment of breast cancer. This is supposed to be the content of bioactive compounds in the bulb, that are naphtaquinone derivatives, i.e elecanacine, eleutherine, eleutherol, and eleutherinone [1].

Some of the naphtaquinone derivatives from Eleutherine Americana Merr. such as eleutherinol, isoeleutherin, eleutherin, hongconin, and dihydroeleutherinol shown to have potential in the inhibitory activity of nitric oxide production in RAW 264.7 lipopolysaccharide-activated mouse macrophage cells [2]. Eleutherine and isoeleutherine also showed potential anti-tumor activities against HT-1080 cell line and have similar activity with 5-FU [3]. Xu et al. reported that 6,8 - dihydroxy - 3,4 dimethoxy - 1 - methyl anthraquinone - 2 - carboxylic acid methyl ester inhibited the proliferation of human erythroleukimia cancer cell line K562 [4].

The estrogen receptor has a role in the regulation of breast cancer cell proliferation. The estrogen-related receptors (ERR $\alpha, E R R \beta$, and ERR $\gamma$ ) are orphan nuclear receptors which have significant amino acid identity with the estrogen receptors. Diethylstilbestrol stilbenes (DES), tamoxifen (TAM), and 4-hydroxytamoxifen (4OHT) were identified as a high affinity ligand for ERR $\gamma$. It has been observed that 4-OHT as molecules that can regulate the transcriptional activity of ERR $\gamma$ [5].

\footnotetext{
*Corresponding author: Tasia Amelia,
}

E-mail: ameliatasia@student.itb.ac.id
The present study was designed to determine the affinity and interaction of naphtaquinone derivatives of Eleutherine americana Merr. to the estrogen receptor of breast cancer by computational methods through the molecular docking. The results of this research can be used as a basis for further experimental research.

\section{Experimental}

\section{Materials}

The materials used for this study was 3D stucture of human estrogen reseptor alpha, and eleutherine, eleutherinone, eleutherol, isoeleutherine, eleutherinol, dihydroeleutherinol, hongconin, and 6,8- dihydroxy-3,4dimethoxy-1-methyl anthraquinone-2-carboxylic acid methyl ester as ligands. 4-hydroxy tamoxifen was used to validate the program.

\section{Instruments}

All computation work were performed using MSI CX420 with Windows 7 Home Basic, Intel Core i3 2,13 $\mathrm{GHz}, 32$ bit operation system, $488 \mathrm{~GB} \mathrm{HDD}$, and 2,00 GB RAM. ChemDraw Ultra version 8.0, Swiss PdbViewer version 4.04, GaussView version 3.0 and Gaussian $\quad 03 \mathrm{~W}$, OpenBabel version 2.2.3, AutoDockTools version 1.5.6 with AutoDock version 4.2, Discovery Studio version 3.5, Command Prompt, WordPad, and PyMol software have been used to performed the docking procedure. ChemDraw was used to draw the 2D and 3D structures. SwissPdb Viewer was used to separate the protein with its natural ligand. Gauss View version 3.0 and Gaussian $03 \mathrm{~W}$ was used to optimize the ligands. OpenBabel version 2.2.3 was used to convert all optimization output file into PDB file and AutoDock version 4.2 and Command Prompt was 
<smiles>CC/C(=C(\c1ccc(O)cc1)c1ccc(OCCN(C)C)cc1)c1ccccc1</smiles>

(a)<smiles>COc1cccc2c1C(=O)C1=C(CC(C)O[C@H]1C)C2=O</smiles>

(b)<smiles>COc1cccc2c1C(=O)C1=C(C[C@H](C)O[C@H]1C)C2=O</smiles>

(c)<smiles>COc1cccc2c1C(=O)C1=C(CO[C@@H]1S)C2=O</smiles>

(d)<smiles>COc1cccc2cc3c(c(O)c12)[C@@H](C)OC3=O</smiles>

(e)<smiles>Cc1cc(=O)c2c(C)cc3cc(O)cc(O)c3c2o1</smiles>

(f)<smiles>Cc1cc2cc(O)cc(O)c2c2c1C(=O)C[C@@H](C)O2</smiles>

(g)<smiles>COc1cccc2c(O)c3c(c(O)c12)[C@@H](C)O[C@@H](C)C3=O</smiles>

(h)<smiles>COC(=O)c1c(C)c2c(c(OC)c1OC)C(=O)c1cc(O)cc(O)c1C2=O</smiles>

(i)

Figure 1. (a) 4-hydroxytamoxifen (natural ligand); Components of Eleutherine americana MERR.: (b) Eleutherine; (c) Isoeleutherine; (d) Eleutherinone; (e) Eleutherol; (f) Eleutherinol; (g) Dihydroeleutherinol; (h) Hongconin; and (i) 6,8-dihydroxy-3,4-dimethoxy-1methyl-anthraquinone-2-carboxylic acid methyl ester.

employed to perform the docking procedure. Discovery Studio version 3.5 was used to confirmed all hydrogen bonds. PyMol was used to produce high resolution pictures. WordPad was used to read all DLG file.

\section{Protein Preparation}

Structure of human estrogen reseptor alpha submitted by Shiau et al. to the protein data bank website (http://www.rscb.org/; PDB code: 3ERT) [6] was employed as the protein target. SwissPdbViewer version 4.04 was used to remove natural ligand from the protein structure.

\section{Ligand Preparation}

Structure of ligands, eleutherine, eleutherinone, eleutherol, isoeleutherine, eleutherinol, dihydro eleutherinol, hongconin, and 6,8-dihydroxy-3,4dimethoxy-1-methyl anthraquinone-2-carboxylic acid methyl ester were prepared by GaussView version 3.0 and optimized by Hartree-Fock method with basis set 3 $21 \mathrm{G}$ and then continued with basis set $6-311 \mathrm{G}$. The LOG output file was converted to PDB file by using OpenBabel version 2.2.3.

\section{Program Validation}

SwissPdb Viewer version 4.04 was used to select and separate the natural ligand (4-hydroxytamoxifen/ OHT) from the protein (human estrogen reseptor alpha/3ERT). OHT was restored as a pdb file. AutoDock version 4.2 was performed to validate docking procedure. Both of protein and ligand were prepared by adding hydrogens, computing charges, and merging the non polar. The used grid box parameter was $36 \times 36 \times 36$, with spacing of $0.375 \AA$ and coordinate of center grid box was 30.01 , $-1.913,24.207$, respectively. Data was saved as GPF file Genetic Algorithm (GA) was used as the parameter, and the number of GA run was 100. Docking parameter was set as default, and the output was obtained by Lamarckian GA as DPF file.

Command prompt was used to complete the docking procedure and the output obtained was DLG file, validity of docking procedure was evaluated based on Root Mean Square Deviation (RMSD) by using WordPad, and the acceptance criteria are good (RMSD $<2 \AA$ ), acceptable

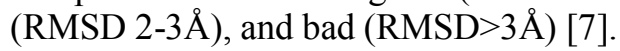
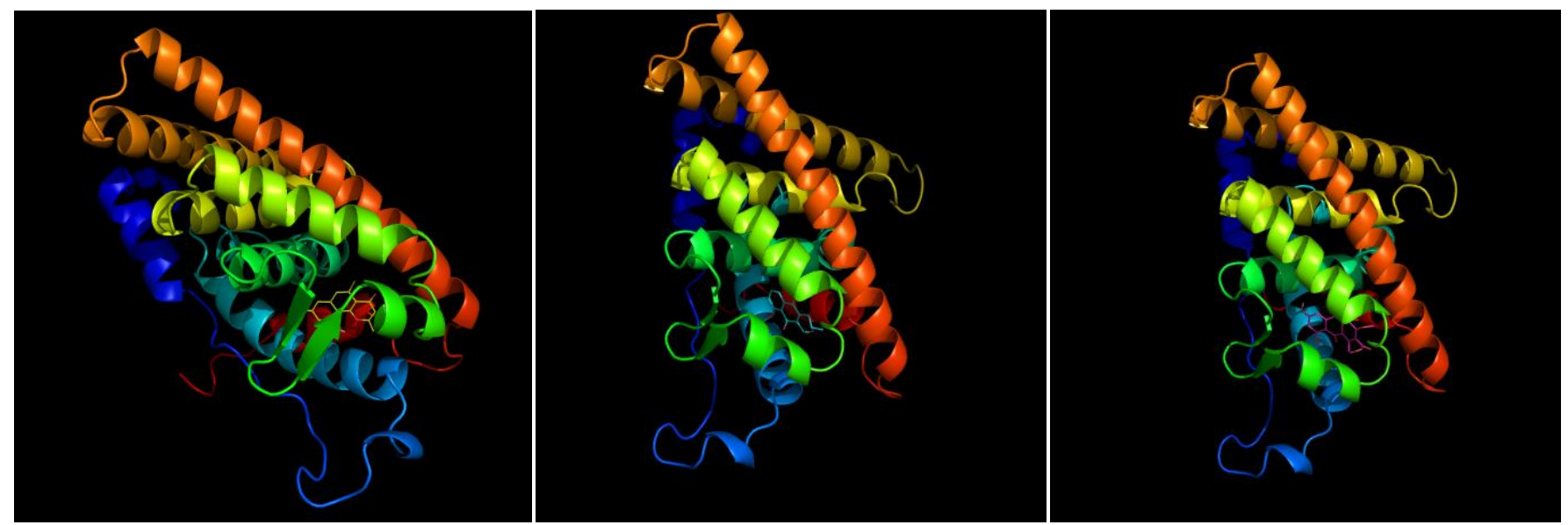

Figure 2. Docking result of three components with highest binding affinity, visualized using PyMol: Eleutherinol (Left); Eleutherine (Center); Dihydroeleutherinol (Right). 
Table 1. The docking result of E.americana compounds to 3ERT

\begin{tabular}{|c|c|c|c|c|c|}
\hline No. & Compounds & $\begin{array}{c}\Delta G \\
(\mathrm{kcal} / \mathrm{mol})\end{array}$ & $\begin{array}{c}\mathrm{KI} \\
(\mu \mathrm{M})\end{array}$ & $\begin{array}{l}\Sigma \text { Hydrogen } \\
\text { bond }\end{array}$ & Amino acid Residue \\
\hline 1 & Eleutherinol & -6.43 & 19.27 & 2 & Glu353, Arg394 \\
\hline 2 & Eleutherine & -6.06 & 35.93 & - & - \\
\hline 3 & Dihydroeleutherinol & -5.94 & 44.61 & 2 & Glu353, Arg394 \\
\hline 4 & Isoeleutherine & -5.85 & 51.19 & - & - \\
\hline 5 & $\begin{array}{l}6,8 \text { - dihydroxy - } 3,4 \text { - dimethoxy - } 1 \text { - } \\
\text { methyl anthraquinone - } 2 \text { - carboxylic acid } \\
\text { methyl ester }\end{array}$ & -5.43 & 104.19 & 3 & Leu346, Leu387, Arg394 \\
\hline 6 & Eleutherinone & -5.18 & 159.02 & 1 & Glu353 \\
\hline 7 & Eleutherol & -5.06 & 195.29 & 1 & Arg394 \\
\hline 8 & Hongconin & -4.90 & 44.61 & 1 & Leu346 \\
\hline
\end{tabular}

\section{Docking}

Docking was performed using AutoDock version 4.2. Each ligand was docked to human estrogen reseptor alpha. Similar procedures, as described in program validation subsection, were applied for the docking study.

\section{Data Analysis and Interpretation}

The output file of docking was analyzed using AutoDock version 4.2. Protein and DLG file was opened to show the interaction between ligand and amino acid residues. WordPad also used to show the estimated free binding energy $(\Delta G)$ and estimated inhibition constant (Ki). All ligands data were compared to descibe the highest binding affinity with lowest free energy of binding and inhibition constant, and the number of hydrogen bonds between ligand and protein. It is also compared to the natural ligand to compare their highest binding affinity to human estrogen receptor alpha.

\section{Results and Discussion}

The redocking of OHT to 3ERT resulted in information of RMSD value, free binding energy, inhibition constant, and number of hydrogen bonds. The best docking poses obtained reproduce the RMSD of 1.021 , which meet in first acceptance criteria as good (RMSD $<2 \AA$ ) [7].

The result showed free binding energy of $-8.7 \mathrm{kcal} / \mathrm{mol}$ and inhibition constant of $418.36 \mathrm{nM}$ at $298.15 \mathrm{~K}$. OHT showed 2 hydrogen bonds to Arg394 and Glu 353 of protein binding site, with the distances of $1.853 \AA$ and $1.85 \AA$, respectively.

The docking result of 8 compounds of Eleutherine americana MERR are presented at Table 1. Eleutherinol has the highest binding affinity with $\Delta E$ of -6.43 $\mathrm{kcal} / \mathrm{mol}$ and $\mathrm{Ki}$ of $19.27 \mu \mathrm{M}$, followed by eleutherin with $\Delta E$ of $-6.06 \mathrm{kcal} / \mathrm{mol}$ and $\mathrm{Ki}$ of $35.93 \mu \mathrm{M}$, and dihydroeleutherinol with $\Delta E$ of $-5.94 \mathrm{kcal} / \mathrm{mol}$ and $\mathrm{Ki}$ of $44.61 \mu \mathrm{M}$ (Figure 2).

Even though eleutherine and isoeleutherine have comparable free binding energy and inhibition constant, however both compounds do not have any interaction to protein binding site after docked by using AutoDock and confirmed by using Discovery Studio version 3.5. Thus, although the previous study have proved that eleutherine and isoeleutherine have a potent anti-tumor activity against HT-1080 cell line with IC50 of $11.74 \mathrm{mg} / \mathrm{mL}$ and have a similar activity with 5-FU [3], both cannot inhibit human estrogen receptor alpha. Garret et al. has explained empirical binding free energy function as the function below:

$$
\begin{gathered}
\Delta \mathrm{G}=\left(\Delta \mathrm{G}_{\mathrm{vdw}}+\Delta \mathrm{G}_{\text {hbound }}+\Delta \mathrm{G}_{\text {desolv }}+\Delta \mathrm{G}_{\mathrm{FI}}+\right. \\
\left.\Delta \mathrm{G}_{\text {elec }}\right)+\Delta \mathrm{G}_{\mathrm{FTI}}+\Delta \mathrm{G}_{\mathrm{tor}}-\Delta \mathrm{G}_{\text {unbound }}
\end{gathered}
$$

where $\Delta \mathrm{G}_{\mathrm{vdw}}$ is van der wals energy, $\Delta \mathrm{G}_{\mathrm{hbond}}$ is hydrogen bound energy, $\Delta \mathrm{G}_{\text {desolv }}$ is desolvation energy, $\Delta \mathrm{G}_{\mathrm{FI}}$ is final intermolecular energy, $\Delta \mathrm{G}_{\text {elec }}$ is electrostatic energy, $\Delta \mathrm{G}_{\mathrm{FTI}}$ is final total internal energy, $\Delta \mathrm{G}_{\mathrm{tor}}$ is torsional free energy, and $\Delta \mathrm{G}_{\text {unbound }}$ is unbound system energy [8]. This function can prove that low free binding energy not only caused by hydrogen bounds, but also another energies involved in that function.

\section{Conclusions}

The naphtaquinone compound from E. americana with the highest binding affinity toward human estrogen reseptor alpha is eleutherinol, with free binding energy of $-6.43 \mathrm{kcal} / \mathrm{mol}$ and has two hydrogen bond interction with Glu353 and Arg394. It shows that eleutherinol is the most potent component of E. Americana to inhibit human estrogen receptor alpha.

\section{References}

[1] E.M. Kuntorini and L.H. Nugroho, Structural development and bioactive content of red bulb plant (Eleutherine americana); a traditional medicines for local Kalimantan people, Biodiversitas, 11(2), 2010, 102-106.

[2] A.R. Han, H.Y. Min, J.W. Nam, N.Y. Lee, A. Wiryawan, W. Suprapto, S.K. Lee, K.R. Lee, and E.K. Seo, Identification of a new naphthalene and its derivatives from the bulb of Eleutherine americana with inhibitory activity on lipopolysaccharide-induced nitric oxide production, Chem. Pharm. Bull., 56(9), 2008, 1314-1316.

[3] I.K. Adnyana, Sukrasno, and S. Kusmardiayani, Antitumor and immunostimulant activities of Eleutherine americana extract and isolation of its active components, Seminar Prosiding on Research Findings Assisted by The Asahi Glass Foundation, Bandung, West Java, Indonesia, 5th August 2010. 
[4] J. Xu, F. Qiu, W. Duan, G. Qu, N. Wang, and X. Yao, New bioactive constituents from Eleutherine Americana, Chem. $J$ Chinese. $U, \mathbf{2 6}(11), 2005$.

[5] P. Coward, D. Lee, M.V. Hull, and J.M. Lehmann, 4hydroxitamoxifen binds to and deactives the estrogenrelated reseptor $\gamma, P N A S, \mathbf{9 8}(15), 2001,8880-8884$.

[6] A.K. Shiau, D. Barstad, P.M. Loria, L. Cheng, P.J. Kushner, D.A. Agard, and G.L. Greene, The structural basis of estrogen receptor/ coactivator recognition and the antagonism of this interaction by tamoxifen, Cell, 95, 1998, 927-937.

[7] I. Daniela, L. Crisan, and L. Pacureanu. Docking experiment for (3S,5S,6S)-6-acetylamidopenicillanic acid, Rev. Chem., 62(8), 2011, 806-809.

[8] G.M. Morris, D.S. Goodsell, R.S. Halliday, R. Huey, W.E. Hart, R.K. Bellew, and A.J. Olson, Automated docking using a Lamarckian Genetic Algoritm and an empirical free energy function., J. Comput. Chem., 19(14), 1998, 16391662 . 